\title{
A NEW SPECIES OF THE GENUS ACHONDROSTOMA ROBALO, ALMADA, LEVY \& DOADRIO, 2007 (ACTYNOPTERIGII, CYPRINIDAE) FROM WESTERN SPAIN
}

\author{
I. Doadrio* y B. Elvira
}

\begin{abstract}
A new freshwater fish species, Achondrostoma salmantinum, formerly considered as one population of Iberochondrostoma lemmingii, is described on the basis of genetic and morphological characters. The new species inhabits the rivers Huebra, Águeda and Uces and tributaries in the Duero River basin in Salamanca province, western Spain. The species is distinguished from Iberochondrostoma lemmingii and from other species of the genus Achondrostoma according to morphometric, meristic and genetic characters such as a narrow caudal peduncle, long postorbital and head lengths, small number of scales (9-10/44-53/4-6), small number of gill rakers (15-22), usually 5-5 pharyngeal teeth, four diagnostic isozyme loci (IDHP-2*,IDHP-3*, $M D H-B^{*}$ and $\left.P E P^{*}\right)$ and one unique allele $\left(M D H-A^{*} 95\right)$. The distribution of $I$. lemmingii is currently known to be restricted to the Tajo, Guadiana, Odiel and Guadalquivir basins. This new cyprinid is considered Endangered (EN) according to IUCN Red List Categories.
\end{abstract}

Key words: Cypriniformes, freshwater fishes, taxonomy, Duero River, Iberian Peninsula.

\section{RESUMEN}

Una nueva especie del género Achondrostoma Robalo, Almada, Levy \& Doadrio, 2007 (Actynopterigii, Cyprinidae) del oeste de España

Se describe una nueva especie de pez de agua dulce, Achondrostoma salmantinum, anteriormente considerada como una población de Iberochondrostoma lemmingii, a partir de caracteres genéticos y morfológicos. La nueva especie vive en la cuenca del río Duero en los ríos Uces, Huebra y Águeda y sus afluentes en la provincia de Salamanca en el oeste de España. De acuerdo con los caracteres morfométricos y genéticos la especie se distingue de Iberochondrostoma lemmingii y de otras especies del género Achondrostoma por un pedúnculo caudal estrecho, larga longitud de la cabeza y de la distancia postorbital, pequeño número de escamas (9/10/44-53/4-6), pequeño número de branquispinas (15-22), frecuentemente 5-5 dientes faríngeos, cuatro loci isozimáticos diagnósticos (IDHP-2*, $I D H P-3^{*}, M D H-B^{*}$ and $\left.P E P^{*}\right)$ y un único alelo $\left(M D H-A^{*} 95\right)$. La distribución de I. lemmingii se restringe ahora a las cuencas de los ríos Tajo, Guadiana, Odiel y Guadalquivir. Este nuevo ciprínido es considerado En Peligro (EN) de acuerdo a las categorías de la Lista Roja de la UICN.

Palabras clave: Cypriniformes, peces de agua dulce, taxonomía, Río Duero, península Ibérica.

\footnotetext{
* Department of Biodiversity, National Museum of Natural Sciences ,C.S.I.C. José Gutiérrez Abascal 2, E-28006 Madrid, Spain Department of Zoology and Physical Anthropology, Faculty of Biology, Complutense University of Madrid, E-28040 Madrid, Spain

* Author to whom correspondence should be addressed. Tel.: +34 91 3944946; fax: +34 91 3944947; email: belvira@bio.ucm.es
} 


\section{Introduction}

The taxonomy of the genus Chondrostoma Agassiz, 1832 was revised by Elvira (1987a, b, 1991, 1997). However, several new species of this genus have been recently described for western Europe (Doadrio \& Carmona, 2003a; Coelho et al., 2005; Robalo et al., 2005). The phylogeny of Chondrostoma has been analysed by Durand et al. (2003); Doadrio \& Carmona (2003b, 2004) and Robalo et al. (2007).

Recent studies based on cytochrome $b$ gene sequences have shown that the genus Chondrostoma in the Iberian Peninsula is composed of a monophyletic assemblage of four independent lineages morphologically and genetically well differentiated (Zardoya \& Doadrio, 1999; Doadrio \& Carmona, 2004). These four lineages have been currently described as different genera (Robalo et al., 2007): 1) Pseudochondrostoma, which includes Ps. polylepis (Steindachner, 1864), Ps. willkommii (Steindachner, 1866), and Ps. duriense (Coelho, 1985); 2) Parachondrostoma, comprising, in the Iberian Peninsula, $P$. arrigonis (Steindachner, 1866), $P$. miegii (Steindachner, 1866) and $P$. turiense (Elvira, 1987); 3) Iberochondrostoma, comprising I. lemmingii (Steindachner, 1866), I. lusitanicum (Collares-Pereira, 1980), I. oretanum (Doadrio \& Carmona, 2003), I. almacai (Coelho, Mesquita \& Collares-Pereira, 2005), and 4) Achondrostoma, including A. arcasii (Steindachner, 1866), A. oligolepis (Robalo, Doadrio, Almada \& Kottelat, 2005), A. occidentale (Robalo, Almada, Santos, Moreira \& Doadrio, 2005), and the new species described here.

In this paper, comparisons are made with Achondrostoma species and Iberochondrostoma lemmingii populations because all previous studies have ascribed the new species from the Duero basin to I. lemmingii (see Doadrio, 2002). Achondrostoma is characterized by small species with arched mouths lacking a horny blade, developed and upward oriented processes from premaxilla and dentary with a coronoid process posteriorly oriented and a long anterior process (Robalo et al., 2007). The same molecular material examined by Carmona et al. (2000) from the Huebra and Turones basins was employed here to describe the new species.

Carmona et al. (2000) observed a high level of genetic divergence between the I. lemmingii populations from the Duero and Guadalquivir basins. The Duero population seems to have started differentiation during the Messinian period in the Cenozoic (Carmona et al., 2000) and bears four diagnostic loci. In addition, a morphological study revealed that the morphometric and meristic characters of the Duero basin population differed from those of I. lemmingii populations in other river basins (Casado, 1995). The material studied by Casado (1995) has been reviewed and is included in this description of the new species.

The purpose of this study is to describe a new freshwater fish species according to several genetic and morphological differences detected between populations from the Duero drainage and those of $I$. lemmingii inhabiting other basins (Casado, 1995; Carmona et al., 2000; Doadrio \& Carmona, 2003b, 2004).

\section{Materials and Methods}

The specimens of the new species analysed are listed in the species description. All specimens were collected from the Duero River basin in Salamanca, western Spain and have been deposited in the National Museum of Natural Sciences, Madrid, Spain.

Twenty-three morphometric variables were measured according to Elvira (1987a, b) and Holcík (1989). All measurements were taken in millimetres and log-transformed for morphometric analysis. A t-test for unbalanced variances was used to analyse sexual dimorphism. The level of statistical significance was set at $P<0.01$. The following abbreviations were used for the morphometric and meristic characters determined: SL, standard length; HL, head length; PrOL, preorbital length; ED, eye diameter; PsOL, postorbital length; ID, interorbital distance; PrDD, predorsal distance; PrPD, prepectoral distance, PrVD, prepelvic distance; PrAD, preanal distance; CPL, caudal peduncle length; APL, anal peduncle length; PVL, pectoral-ventral length; DFL, dorsal fin length; DFH, dorsal fin height; PFL, pectoral fin length; VFL, ventral fin length; AFL, anal fin length; AFH, anal fin height; CFL, caudal fin length; BD, body depth; BLD, least body depth; LLS, number of lateral line scales; LTU, number of upper transverse line scales; LTL, number of lower transverse line scales; D, number of dorsal fin rays; A, number of anal fin rays; $\mathrm{P}$, number of pectoral fin rays; $\mathrm{V}$, number of pelvic fin rays; $C$, number of caudal fin rays; GR, number of gill rakers; $\mathrm{PT}$, number of pharyngeal teeth. Only branched fin rays were counted. Osteological characters were examined and studied in clear and stained specimens (Wassersug, 1976). 


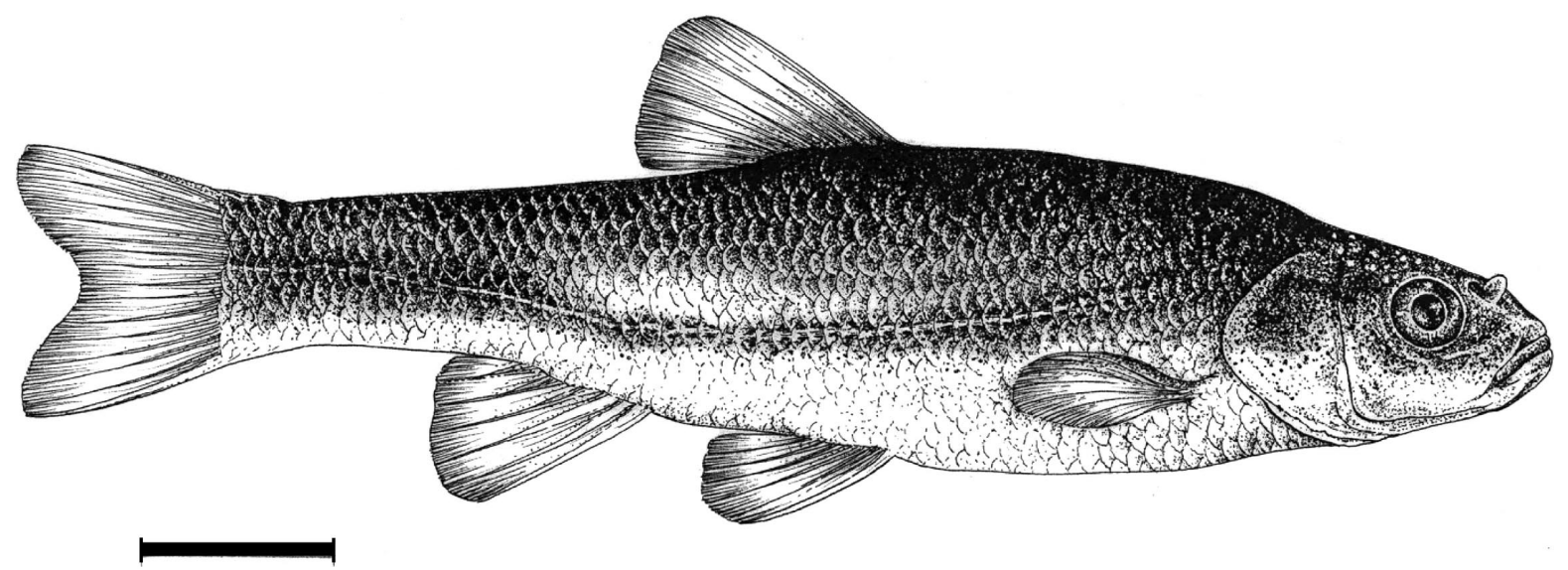

Fig. 1.- Achondrostoma salmantinum sp. nov. MNCN 238512, female, 53.8 mm SL, Huebra River, San Muñoz, Salamanca, Duero basin, Spain. Scale $=1 \mathrm{~cm}$.

Fig. 1.- Achondrostoma salmantinum sp. nov. MNCN238512, hembra, 53.8 mm SL, río Huebra, San Muñoz, Salamanca, cuenca del Duero, España. Escala $=1 \mathrm{~cm}$.

Institutional acronyms: MNCN Museo Nacional de Ciencias Naturales, Madrid, Spain; NMW Naturhistorisches Museum Wien, Vienna, Austria.

Comparison with local Iberochondrostoma endemisms from Portugal (I. almacai, I. lusitanicum) and Guadalquivir basin (I. oretanum) are not shown because of their well-recognized genetic differences and geographic isolation (Doadrio \& Carmona, 2003b and 2004). The purpose of this study is to demonstrate that within the populations of the Duero basin traditionally recognized as $I$. lemmingii, one species -widely extended by Iberian Peninsula- is really a different species. For this reason analyses of the I. lemmingii populations were done. Currently, genetic studies have demonstrated that one population of I. lemmigii from the Duero basin is a well differentiated species phylogenetically closer to Achondrostoma than to Iberochondrostoma (Robalo et al., 2007). We also show the morphological differences of the new species with Achondrostoma species.

\section{Results}

The high degree of genetic (Carmona et al., 2000; Doadrio \& Carmona, 2003b, 2004) and morphological divergence found between the specimens from the Duero basin and I. lemmingii from the other river basins, support the existence of a new species in the Duero basin. Since no available name can be applied to the Duero specimens, a new species is described.

\section{Achondrostoma salmantinum sp. nov.}

Holotype. (Fig. 1, Table 1). MNCN 238512, female, $53.8 \mathrm{~mm}$ SL. Huebra River, San Muñoz, Salamanca, Duero basin, Spain. Leg. I. Doadrio and P. Garzón. 15 April 2001.

PARATyPes. (Tables 1 and 2). MNCN 238513-86, 74 ex., Huebra River, San Muñoz, Salamanca, Duero basin, Spain. Leg. I. Doadrio and P. Garzón. 15 April 2001. MNCN 194610-15, 6 ex., Gavilanes River, Sancti-Spiritus, Salamanca, Duero basin, Spain. Leg. I. Doadrio and B. Elvira. 22 March 1978. MNCN 114949-63, MNCN 167503-35, 47 ex., Huebra River, Carrascalejo de Huebra, Salamanca, Duero basin, Spain. Leg. J. A. Carmona, A. Perdices and J. C. Velasco (material studied by Casado, 1995 and by Carmona et al., 2000). MNCN 13831215, 4 ex., Huebra River, Cubo de Don Sancho, Salamanca, Duero basin, Spain. Leg. L. Pardo. 19 January 1943. MNCN 50785-896, 112 ex., Huebra River, San Muñoz, Salamanca, Duero basin, Spain. Leg. I. Doadrio. 17 April 1989. MNCN 29466-98, MNCN 29430-31, 35 ex., Huebra River, Tamames, Salamanca, Duero basin, Spain. Leg. I. Doadrio and B. Elvira. 17 August 1981. MNCN 138427-28, 2 ex., Rugidero Stream, Cubo de Don Sancho, Salamanca, Duero basin, Spain. Leg. L. Pardo. June 1944. MNCN 167960-93, 34 ex., Turones River, Bouza, Salamanca, Duero basin, Spain. Leg. I. Doadrio, J. A. Carmona and P. Garzón (material studied by Carmona et al., 2000). 26 November 1994. MNCN 29343-49, 7 ex., Yeltes River, San Martín de Yeltes, Salamanca, Duero basin, Spain. Leg. I. Doadrio and B. Elvira. 17 August 1981. MNCN 21832254, 33 ex., Yeltes River, Pedraza de Yeltes, Salamanca, Duero basin, Spain. Leg. I. Doadrio. 24 October 1987.

The comparative material of related species including the type series, is as follows: Iberochondrostoma lemmingii: NMW 
Table 1.- Statistical parameters for the morphometric characters of the holotype and 39 paratypes of $A$. salmantinum sp. nov. from the Huebra River. Variables as described in Materials and Methods. Variables showing significant differences $(\mathrm{P}<0.01)$ between sexes are marked $*$.

Tabla 1.- Parámetros estadísticos para los caracteres morfométricos del holotipo y 39 paratipos de A. salmantinum sp. nov. del río Huebra. Las variables son descritas en material y métodos. Las variables con diferencias significativas $(\mathrm{P}<0.01)$ entre sexos son marcadas *

\begin{tabular}{|c|c|c|c|c|c|c|c|}
\hline \multirow[b]{2}{*}{ Variable } & \multicolumn{4}{|c|}{ Females $(n=19)$} & \multicolumn{3}{|c|}{ Males $(n=20)$} \\
\hline & Holotype & Range & Mean & SD & Range & Mean & SD \\
\hline SL & 53.8 & $41.6-80.6$ & 52.14 & 6.73 & $46.4-68.2$ & 56.48 & 5.25 \\
\hline HL & 13.5 & $10.7-20.6$ & 13.27 & 1.60 & $12.2-16.8$ & 14.14 & 0.99 \\
\hline PrOL & 3.8 & $2.9-5.8$ & 3.74 & 0.47 & $3.2-5.3$ & 4.01 & 0.51 \\
\hline ED & 3.1 & $2.6-4.4$ & 3.23 & 0.39 & $2.6-4.1$ & 3.41 & 0.27 \\
\hline PsOL & 6.4 & $5.3-10.8$ & 6.59 & 0.98 & $5.5-8.3$ & 6.80 & 0.59 \\
\hline ID & 4.4 & $3.3-6.3$ & 4.22 & 0.49 & $3.7-5.5$ & 4.56 & 0.42 \\
\hline PrDD & 29.3 & $23.4-43.4$ & 28.52 & 3.84 & $24.5-37.1$ & 29.92 & 2.85 \\
\hline PrPD & 13.6 & $11.5-20.7$ & 13.79 & 1.62 & $12.2-17.5$ & 14.69 & 1.20 \\
\hline PrVD & 27.8 & $21.4-40.1$ & 26.76 & 3.39 & $24.5-33.2$ & 27.73 & 2.29 \\
\hline PrAD & 37.2 & $28.4-46.0$ & 35.74 & 4.07 & $31.9-45.9$ & 37.76 & 3.63 \\
\hline CPL & 19.3 & $16.3-30.3$ & 19.60 & 2.44 & $17.9-27.1$ & 21.28 & 2.23 \\
\hline APL & 11.3 & $9.2-17.2$ & 11.76 & 1.52 & $11.0-16.6$ & 13.23 & 1.39 \\
\hline PVL & 12.5 & $10.0-17.0$ & 12.40 & 1.71 & $10.4-15.8$ & 12.66 & 1.53 \\
\hline DFL & 5.5 & $3.8-9.2$ & 5.32 & 0.84 & $5.0-8.2$ & 6.10 & 0.69 \\
\hline DFH & 8.9 & $6.6-12.8$ & 8.73 & 1.18 & $7.2-12.3$ & 9.76 & 0.93 \\
\hline *PFL & 9.3 & $7.3-13.9$ & 9.36 & 1.24 & $9.7-12.8$ & 11.11 & 0.70 \\
\hline *VFL & 7.7 & $5.4-10.3$ & 7.02 & 1.10 & $7.2-10.9$ & 8.88 & 0.76 \\
\hline *AFL & 4.9 & $4.1-7.3$ & 5.20 & 0.70 & $3.9-7.9$ & 5.99 & 0.79 \\
\hline *AFH & 7.6 & $5.8-10.2$ & 7.40 & 1.02 & $7.3-11.1$ & 8.79 & 0.83 \\
\hline CFL & 8.9 & $6.8-12.4$ & 8.79 & 1.31 & $8.0-11.8$ & 9.81 & 1.02 \\
\hline $\mathrm{BD}$ & 13.5 & $10.2-19.2$ & 13.32 & 1.65 & $10.7-15.5$ & 12.78 & 1.34 \\
\hline BLD & 5.0 & $4.2-8.8$ & 5.41 & 0.80 & 4.4-7.3 & 5.73 & 0.57 \\
\hline LLS & 47 & $44-51$ & 48.42 & 1.35 & $46-53$ & 49.75 & 1.88 \\
\hline LTU & 9 & $9-10$ & 9.84 & 0.27 & $9-10$ & 9.40 & 0.48 \\
\hline LTL & 5 & $5-6$ & 5.68 & 0.43 & $4-6$ & 5.40 & 0.54 \\
\hline D & 7 & 7 & 7.00 & 0.00 & $6-7$ & 6.90 & 0.18 \\
\hline A & 7 & $6-7$ & 6.89 & 0.19 & $6-7$ & 6.80 & 0.32 \\
\hline
\end{tabular}

52356, 4 ex., NMW 52357, 2 ex., NMW 52366, 2 ex., NMW 52373, 4 ex. Syntypes of Leuciscus lemmingii Steindachner, 1866. Mérida, Badajoz, Guadiana basin, Spain. Leg. F. Steindachner. December 1864. NMW 52363, 2 ex., Syntypes of Leuciscus lemmingii Steindachner, 1866. Sevilla, Guadalquivir basin, Spain. Leg. F. Steindachner. December 1864. MNCN 29035-7, 3 ex., Alburrel River, Valencia de Alcántara, Cáceres, Tajo basin, Spain. Leg. I. Doadrio. 12 May 1985. MNCN 29718-38, 21 ex., Salor River, Cáceres. Tajo basin, Spain. Leg. L. Lozano-Rey. August 1930. MNCN 29015-34, 30 ex., Aljucén River, Aljucén, Badajoz, Guadiana basin, Spain. Leg. L. Lozano-Rey. August 1930. MNCN 29739-68, 30 ex., Ortigas River, Magacela, Badajoz, Guadiana basin, Spain. Leg. I. Doadrio. 29 December 1984. MNCN uncat., 30 ex., Quejigares River, Fontanosas, Ciudad Real, Guadiana basin, Spain. Leg. I. Doadrio. 6 August 1984. MNCN 29367-73, 6 ex., Cascabelero River, Villanueva de las Cruces, Huelva, Odiel basin, Spain. Leg. I. Doadrio. 12 April 1979. MNCN 29246-74, 29 ex., Bembézar River, Azuaga, Badajoz, Guadalquivir basin, Spain.
Leg. I. Doadrio. 28 December 1984. Hybrids Ps. duriense x $A$. arcasii: NMW 52569, 5 ex. Syntypes of I. lemmingii steindachneri Berg, 1932. Tera River, Sanabria, Zamora, Duero basin, Spain. Leg. F. Steindachner. December 1864. Achondrostoma oligolepis MNCN 037607-10, 3 ex., Areia River, Valado der Frades, Alcoa basin, Portugal, Leg. M. J Collares-Pereira, 26 March 1978. MNCN 055001-7, 7 ex. Arunca River, Sourepont, Mondego basin, Portugal, 13 october, 1986. MNCN 055008-15, 8 ex., Ave River, Azurem, Ave basin, Portugal, Leg. Y Bernat and J. Cubo, 7 April 1990. MNCN 055016-22, 7 ex., Velho River, Pogo da Cal, Mondego basin, Portugal, 22 October 1986. MNCN 055023-34, 12 ex., Cavado River, Prados, Cavados basin, Portugal, Leg. Y. Bernat and J. Cubo, 7 April 1989. MNCN 055035-39, 5 ex., Mondego River, Formoselma, Mondego basin, Portugal, 16 october 1986. MNCN 055040-50, 11 ex., Sousa River, Recarei, Duero basin, Portugal, Leg., Y. Bernat and J. Cubo. 10 april 1989. MNCN 257357-61, 5 ex., Neiva River, Vilaverde, Duero basin, Portugal, Leg., I. Doadrio, 6 juni-2004. MNCN 257364-68, 5 ex., Cavado tributary, Braga, 
Table 2.- Summary of diagnostic characters of $A$. salmantinum sp. nov. The sample of $I$. lemmingii contains 163 individuals from all the basins where the species is present. Values for $A$. occidentale are of Robalo et al. (2005). We indicate the mean and the range, in parentheses.

Tabla 2.- Resumen de los caracteres diagnósticos de A. salmantinum sp. nov. La muestra de I. lemmingii contiene 163 individuos de todas las cuencas donde está presente. Valores para $A$. occidentale de Robalo et al. (2005). Se indica la media y, entre paréntesis, el rango.

\begin{tabular}{|c|c|c|c|c|c|}
\hline Character & $\begin{array}{l}\text { A. salmantinum } \\
(\mathrm{n}=40)\end{array}$ & $\begin{array}{l}\text { I. lemmingii } \\
(\mathrm{n}=163)\end{array}$ & $\begin{array}{l}\text { A. oligolepis } \\
(\mathrm{n}=70)\end{array}$ & $\begin{array}{l}\text { A. occidentale } \\
(\mathrm{n}=60)\end{array}$ & $\begin{array}{l}\text { A. arcasii } \\
(\mathrm{n}=90)\end{array}$ \\
\hline $\begin{array}{l}\text { Number of pharyngeal teeth } \\
\text { on the left side }\end{array}$ & 5.0 & $5.8(5-6)$ & $5.1(5-6)$ & 5.0 & 5.0 \\
\hline $\begin{array}{l}\text { Number of scales on the } \\
\text { lateral line }\end{array}$ & $49.1(44-53)$ & $59.1(52-66)$ & $38.1(35-41)$ & $42.7(39-47)$ & $43.8(38-48)$ \\
\hline $\begin{array}{l}\text { Number of scales on the } \\
\text { upper transverse line }\end{array}$ & $9.6(9-10)$ & $11.2(10-12)$ & $6.9(6-8)$ & $7.2(6-8)$ & $7.4(7-8)$ \\
\hline $\begin{array}{l}\text { Number of scales on the } \\
\text { lower transverse line }\end{array}$ & $5.5(4-6)$ & $6.0(5-8)$ & $2.9(2-3.5)$ & $3.2(2-4)$ & $4.5(4-5)$ \\
\hline Number of gill rakers & $18.4(15-22)$ & $27.1(24-31)$ & $12.2(12-15)$ & $13.6(12-14)$ & $11.8(9-15)$ \\
\hline Diagnostic isozyme loci & $\begin{array}{l}I D H P-2^{*}, I D H P-3^{*}, \\
M D H-B^{*} \text { and } P E P^{*}\end{array}$ & & & & \\
\hline
\end{tabular}

Portugal, Leg., I. Doadrio, 6-juni-03. Achondrostoma arcasii MNCN 22622-639, 18 ex., Queiles River, Torrella, Zaragoza, Ebro basin, Spain, Leg. I. Doadrio. 18 April 1983. MNCN 109186-109219, 34 ex., Cega River, Pajares de Pedraza, Segovia, Duero basin, Spain, Leg. I. Doadrio, 13 October 1994 Achondrostoma occidentale MNCN244125. Holotype of Chondrostoma occidentale Robalo, Almada, Santos, Moreira \& Doadrio 2005. Safarujo River, Mafra, Safarujo basin, Portugal. Leg. V. Almada, J. Robalo, C. Santos. 9 October 2002. MNCN244123, CM-SAF-MU, 7 ex., Safarujo River. Mafra, Safarujo basin, Portugal. Leg. V. Almada, J. Robalo, C. Santos. 9 October 2002. MNCN244127-128, SIZ-MU 1-9, 11ex., Sizandro River, Torres Vedras, Sizandro Basin, Portugal. Leg. V. Almada, J. Robalo, C. Santos. 9 October 2002. MCN246658677, 20 ex., Sizandro River, Torres Vedras, Sizandro Basin, Portugal. Leg. V. Almada, I. Doadrio, P. Garzón, J. Robalo, C. Santos.

Diagnosis: Achondrostoma salmantinum sp. nov. differs from all other known species of Achondrostoma in terms of the following combination of characters: seven branched rays in the dorsal and anal fins; pharyngeal teeth 5-5; narrow caudal peduncle; number of gill rakers mean $=18.4$ (range $=15-22)$; number of scales on lateral line mean $=49.1(44-53)$; number of scales on upper transverse line mean $=9.6(9-10)$; number of scales on lower transverse line mean $=5.5$ (4-6); four diagnostic isozyme loci (IDHP-2*, IDHP-3*, $M D H-B^{*}$ and $\left.P E P^{*}\right)$ and one unique allele $(M D H-$ $A^{* 95)}$ (Carmona et al., 2000).

DESCRIPTION: The mouth is arched and subterminal lacking a horny layer on the lower lip. Morphometric characters are given in Tables 1 and 2. D
II-III/6-7 (mean $=6.9)$, A II-III/6-7 $($ mean $=6.8), \mathrm{P}$ I/12, V I/7, C I/17/I, LLS 44-53 (mean = 49.1), LTU 9-10 $($ mean $=9.6)$, LTL $4-6($ mean $=5.5)$, PT 5/5, GR 15-22 (mean =18.4). Maximum size for the type series is a female of SL $=80.6 \mathrm{~mm}$. Maximum body depth is 3.5-4.9 (mean = 4.2) times the standard length. Minimum body depth is 3.2-4.2 (mean = 3.7) times the caudal peduncle length. Head length is 3.74.3 (mean $=4.0)$ times the standard length. Postorbital length is 7-9.3 (mean = 8.1) times the standard length. Postorbital length is half the head length. Preorbital length is greater than the eye diameter. Predorsal distance is $1-1.2($ mean $=1.1)$ times the preventral distance. Ventral fins are inserted at, or slightly anterior to, the vertical level of the origin of the dorsal fin. Fin size moderately large.

The species is diploid $(2 \mathrm{n}=50)$, with a fundamental arm number NF $=94$ (García-Utrilla \& Elvira, 1991).

Pigmentation PATTERn: One row of dark spots along the lateral line and body darkly spotted both above and below the lateral line. Dorsum olivebrown with dense black dots, flanks with golden flashes, underside silvery white. Down the lateral line, the body is light brown. Peritoneum is black. All fins have dark spots. Bases of the pectoral, pelvic and anal fins orange to reddish.

Osteology (Fig. 2): The osteological characters of $A$. salmantinum sp. nov. generally resemble those of the genus Achondrostoma (Elvira 1987a,b, 1997). 
A

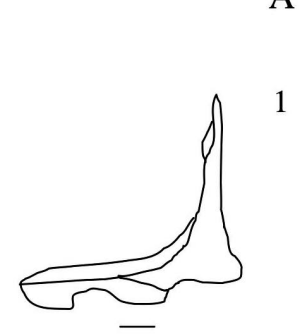

2
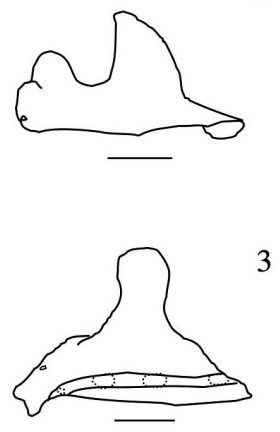

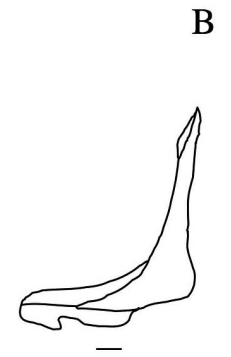

B

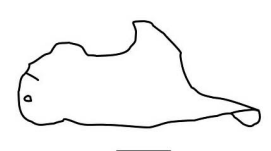

3

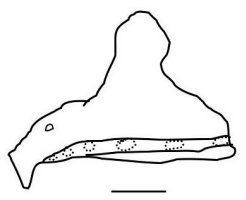

C
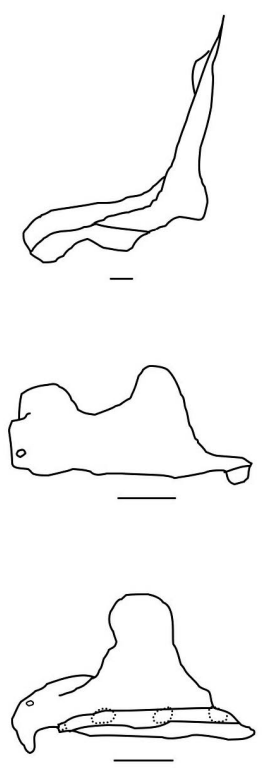

$\mathrm{D}$
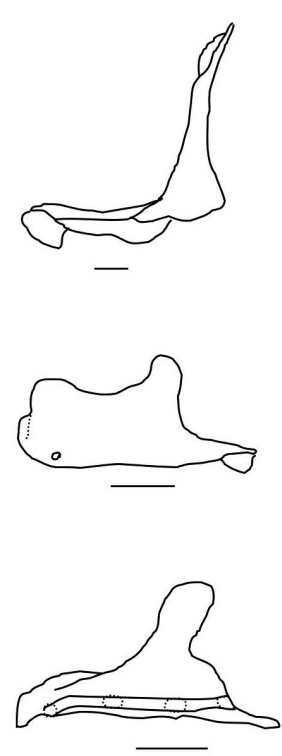

$\mathrm{E}$
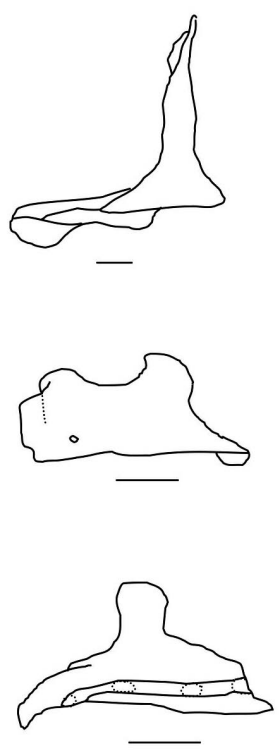

Fig. 2.- Osteological characters.(1) Top: cleithrum. (2) Middle: maxilla. (3) Bottom: dentary. A: A. arcasii. B: A. oligolepis. C: A. occidentale. D: A. salmantinum. E: I. lemmingii. Scale $=1 \mathrm{~mm}$.

Fig. 2.- Caracteres osteológicos. (1) Arriba: cleitro. (2) Centro: maxilar. (3) Abajo: dentario. A: A. arcasii. B: A. oligolepis. C: A. occidentale. D: A. salmantinum. E: I. lemmingii. Escala $=1 \mathrm{~mm}$.

Further bone features are: dentary relatively short, the coronoid process is tall and inclined posteriorly. Palatine process of the maxilla thin and tall. Posterior process of the cleithrum rather short and slightly developed. Compared to I. lemmingii (Fig. 2), the follow differences emerge: the coronoid process of the dentary is tall and inclined posteriorly in $A$. salmantinum, while it is lower and vertical in I. lemmingii. The palatine process of the maxilla is thin and high in A. salmantinum and larger and lower in I. lemmingii. The posterior plate of the cleithrum is rather short and poorly developed in A. salmantinum and rather expanded in I. lemmingii.

SEXUAL DIMORPHISM: Significant differences $(P<$ 0.01 ) were noted in pectoral, pelvic and anal fin sizes. In all specimens, males had longer fins than females (Table 1). Similar sexual differences in fin size were described for Ps. polylepis by Elvira \& Lobón-Cerviá (1984). Likewise, sexual dimorphism in I. lemmingii, I. lusitanicum, A. oligolepis and A. arcasii is similar to that observed in the new species, but less remarkable and apparently limited to differences in ventral fin size between sexes (Collares-Pereira, 1983).
ETYMOLOGY: The species name salmantinum was taken as an adjective derived from Salmantia, the Roman name for Salamanca, the Spanish city and the province inhabited by the species.

COMMON NAME: The local name "Sarda" is proposed as a common name for A. salmantinum.

GeOgRAPHICAL DISTRIBUTION: Achondrostoma salmantinum inhabits the Huebra, Turones and Uces rivers and their tributaries in the Duero basin (Fig. 3 ). Its distribution range encompasses the southwestern region of the Salamanca province of Spain.

REMARKS: Achondrostoma salmantinum sp. nov. typically inhabits seasonal streams, with clear waters, sandy bottoms, and prefers slow flowing reaches with abundant aquatic macrophytes (Elvira et al., 1990; Velasco et al., 1990, 1997). The species occurs in sympatry with other native cyprinids, $P S$. duriense, Barbus bocagei Steindachner, 1865, and Squalius carolitertii (Doadrio, 1987).

Natural hybrids with Ps. duriense have been reported in several localities (Elvira et al., 1990; Velasco et al., 1997). These hybrids are intermedi- 


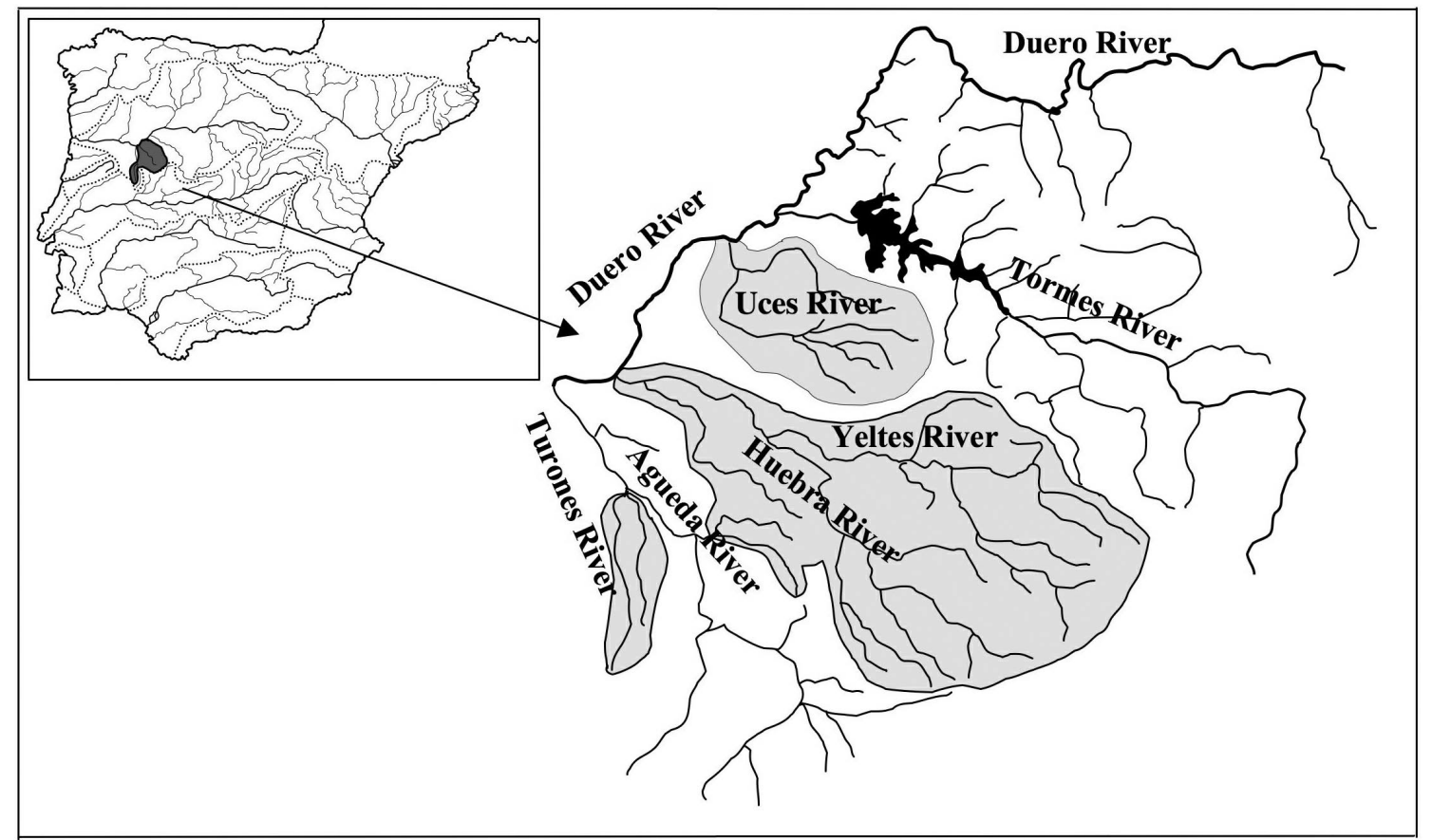

Fig. 3.- Distribution range of A. salmantinum.

Fig. 3.- Área de distribución de A. salmantinum.

ate in shape between the parent species, with a stronger resemblance to Ps. duriense (Elvira et al., 1990).

Velasco et al. (1990) described the age, growth and reproduction of the species in the Huebra River.

CONSERVATION: Achondrostoma salmantinum sp. nov. is locally abundant in its distribution range, where it can be the dominant species in terms of numbers of individuals. However, its habitat has been reduced during the past decades by receding water levels due to extensive agriculture, construction of dams and weirs, and by water transfers. Consequently, the species is currently in decline and should be considered Endangered (EN $\mathrm{B} 1 \mathrm{bc}+2 \mathrm{bc}$ ) according to IUCN Red List Categories (Doadrio, 2002).

\section{Discussion}

Achondrostoma salmantinum $\mathrm{sp}$. nov was shown to be highly differentiated morphologically in a multivariate analysis of 22 morphometric variables with Burnaby correction (Doadrio \& Carmona, 2003) (Fig. 4). The new species differs from I. lemmingii in its more elongated body, narrower caudal peduncle, and longer postorbital and head lengths. Achondrostoma salmantinum has fewer scales and gill rakers than I. lemmingii (Table 2). With respect to other Achondrostoma species A. salmantinum $\mathrm{sp}$. nov has higher number of scales and gill rakers (Table 2)

Chondrostoma lemmingii steindachneri Berg, 1932 was described from the Duero basin based on five specimens from the Tera River, Sanabria, Zamora, Duero basin. These specimens were classified by Elvira (1987a,b) and Elvira et al. (1990) as a hybrid, currently named $P$ s. duriense $\mathrm{x}$ A. arcasii. Similarly, natural hybrids of Ps. duriense x $A$. salmantinum have been reported in several sites of the Duero basin (Elvira et al., 1990; Velasco et al., 1997). These hybrids are intermediate in shape between the parent species, with a stronger resemblance to Ps. duriense (Elvira et al., 1990).

Molecular markers indicate four diagnostic isozyme loci (IDHP-2*, IDHP-3*, $M D H-B^{*}$ and $\left.P E P^{*}\right)$ and one unique allele $\left(M D H-A^{*} 95\right)$ (Carmona et al., 2000) for I. salmantinum. Pairwise sequence diver- 


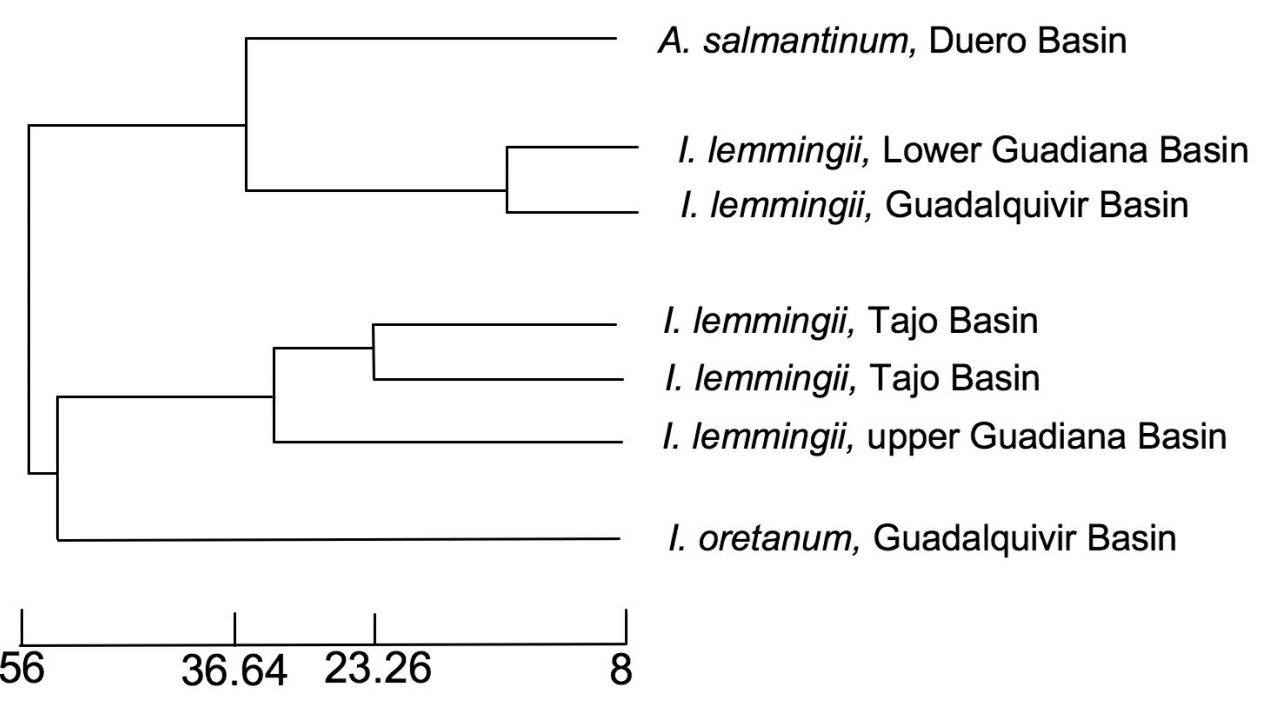

Fig. 4.- Cluster based on a similarity matrix of 22 morphometric variables for the formerly considered I. lemmingii populations (after Doadrio \& Carmona, 2003b). The tree shows the high degree of morphological differentiation of A. salmantinum.

Fig. 4.- Agrupamiento basado en la matriz de similaridad de 22 variables morfométricas para las anteriormente consideradas poblaciones de I. lemmingii (después de Doadrio \& Carmona, 2003b). El árbol muestra el alto grado de diferenciación de $A$. salmantinum.

gences for the complete cytochrome $b$ gene between I. salmantinum and other Iberian Iberochondrostoma species are high (7.5-9.6\%) (Carmona et al., 2000). The high divergence detected in the Duero basin with respect to the other river basins, contrasts with that found among the populations of I. lemmingii from the Tajo, Guadiana and Guadalquivir basins, indicating different levels of genetic differentiation among drainages. Assuming no significant different substitution rate (at the $5 \%$ level) within Iberochondrostoma populations (Zardoya \& Doadrio, 1999), the high genetic divergence shown by the populations of the Duero basin would have to be explained by additional historical events, older than the hydrographical configuration.

The Duero River and other Iberian rivers started to acquire their current drainages during the Plio-Pleistocene (Banarescu, 1989; Calvo et al., 1993). However, palaeogeographical data indicate that the Duero basin split occurred earlier on, and that it arose from an ancient endorrheic lagoon in the Miocene period. Moreover, during the Miocene, the Duero drainage was composed of the former Duero endorrheic basin and the ancient Ciudad Rodrigo endorrheic basin, located in the southwestern portion of the Spanish Duero basin, which almost perfectly matches the current distribution range of the new putative species (LópezMartínez, 1989). According to a molecular clock of $1.05 \%$ sequence divergence per million years for cyprinids (Dowling et al., 2002), the Duero basin population is predicted to have started its differentiation at the edge of Tortonian-Messinian period (7.1 MYA, Berggren et al., 1995). During this period, it is likely that the Duero and Ciudad Rodrigo endorrheic basins almost dried up and became isolated one from the other (Carmona et al., 2000). According to our data, it is believed that C. salmantinum speciation resulted from this isolation of the ancient endorrheic basin of Ciudad Rodrigo (western Spain) prior to the formation of the current Iberian hydrographic basins (Carmona et al., 2000).

\section{ACKNOWLEDGEMENTS}

This study was financially sponsored by a DGES project REM2001-0662/G10. For their assistance with the field collections, the authors thank J. Cubo ("in memoriam"), I. Doadrio Jr., A. Doadrio, P. Garzón, O. Domínguez, M. González and J. 
C. Velasco. Mr. James Watkins and A. Burton revised the English text. The Regional Administration (Junta de Castilla y León) provided the necessary permissions to collect the fish samples.

\section{References}

BANARESCU, P., 1989. Zoogeography and history of the freshwater fish fauna of Europe. In: J. Holcik (ed). The freshwater fishes of Europe. Vol I. Aula-Verlag. Wiesbaden: 88-107.

Berggren, W. A., Kent, D. V., Swisher, C. C. III. \& AuBry, M. P., 1995. A revised Cenozoic geochronology and chronostratigraphy. In: W. A. Berggren, Kent, D. V., Aubry, M. P. and Hardenbol, J. (eds). Geochronology, time scales and global stratigraphic correlation. Society of Economic Palentologists and Mineralogists and Society for Sedimentary Geology, Special Publication, 54: 129-212.

Calvo, J. P., DaAms, R., Morales, J., López-Martínez, N., Agustí, J., AnAdón P. ET AL. (26 autores), 1993. Up-to-date Spanish continental Neogene synthesis and paleoclimatic interpretation. Revista de la Sociedad Geologica de España, 6: 29-40.

CARmona, J. A., Domínguez, J. \& DoAdrio, I., 2000. Congruence between allozyme and cytochrome $b$ gene sequence data in assessing genetic differentiation within the Iberian endemic Chondrostoma lemmingii (Pisces: Cyprinidae). Heredity, 84: 721-732.

CAsado, M. P., 1995. Sistemática del género Rutilus Rafinesque, 1820 en la Península Ibérica. PhD Thesis. Complutense University of Madrid. 438 pp.

Coelho, M. M., Mesquita, N. \& Collares-Pereira, M. J., 2005. Chondrostoma almacai, a new cyprinid species from the southwest of Portugal. Folia Zoologica 54: 201-212.

Collares-Pereira, M. J. 1983. Estudo sistemático e citogenético dos pequenos ciprinídeos ibéricos pertencentes aos géneros Chondrostoma Agassiz, 1835, Rutilus Rafinesque, 1820 e Anaecypris CollaresPereira, 1983. PhD Thesis. University of Lisbon. $511 \mathrm{pp}$.

DoADrio, I. (ed.), 2002. Atlas y libro rojo de los peces continentales de España. $2^{\text {nd }}$ edition. Dirección General de Conservación de la Naturaleza. Madrid. $364 \mathrm{pp}$.

DOADRIO, I. \& CARMONA, J. A., 2003a. A new species of the genus Chondrostoma Agassiz, 1832 (Actinopterygii, Cyprinidae) from the Iberian Peninsula. Graellsia, 59: 29-36.

DoAdrio, I. \& CARMona, J. A., 2003b. Testing freshwater lago mare dispersal theory on the phylogeny relationships of Iberian cyprinid genera Chondrostoma and Squalius (Cypriniformes, Cyprinidae). Graellsia, 59: 457-473.
DoAdrio, I. \& CARMONA, J. A., 2004. Phylogenetic relationships and biogeography of the genus Chondrostoma inferred from mitochondrial DNA sequences. Molecular Phylogenetics and Evolution, 33: 802-815.

Dowling, T. E., TibBets, C. A., Minckley, W. L. \& SмiтH, G. R., 2002. Evolutionary relationships of the plagopterins (Teleostei: Cyprinidae) from cytochrome b sequences. Copeia, 2002(3): 655-678.

Durand, J.-D., Bianco, P. G., Laroche, J. \& Gilles, A., 2003. Insight into the origin of endemic Mediterranean ichthyofauna: phylogeny of Chondrostoma genus (Teleostei, Cyprinidae). Journal of Heredity, 94: 315328.

ElvirA, B., 1987a. A taxonomic revision of the genus Chondrostoma Agassiz, 1835 (Pisces, Cyprinidae). Cybium, 11: 111-140.

ElviRA, B., 1987b. Revisión taxonómica y distribución geográfica del género Chondrostoma Agassiz, 1835 (Pisces, Cyprinidae). Tesis Doctorales I.N.I.A., 62: 1530.

ELVIRA, B., 1991. Further studies on the taxonomy of the genus Chondrostoma (Osteichthyes, Cyprinidae): species from Eastern Europe. Cybium, 15: 147-150.

ElviRA, B., 1997. Taxonomy of the genus Chondrostoma (Osteichthyes, Cyprinidae): an updated review. Folia Zoologica, 46(suppl. 1): 1-14.

Elvira, B. \& LobÓN-CERviá, J., 1984. Diferenciación sexual en la boga de río (Chondrostoma polylepis polylepis Steindachner, 1865) basada en análisis biométrico. Actas de la II Reunión Iberoamericana sobre Conservación y Zoología de Vertebrados, Cáceres: 1-5.

Elvira, B., Rincón, P. A. \& Velasco, J. C., 1990. Chondrostoma polylepis Steindachner x Rutilus lemmingii (Steindachner) (Osteichthyes, Cyprinidae) a new natural hybrid from the Duero River basin, Spain. Journal of Fish Biology, 37: 745-754.

García-Utrilla, C. \& Elvira, B., 1991. Karyology of Rutilus lemmingii (Steindachner, 1866) (Osteichthyes, Cyprinidae) from the Duero River basin. III Jornadas de Ictiología Ibérica, Perlora: 23.

Holcík, J. (ed.), 1989. The Freshwater Fishes of Europe. Vol. 1, Part II. General Introduction to Fishes. Acipenseriformes. AULA-Verlag. Wiesbaden. 469 pp.

LóPEZ-Martínez, N., 1989. Tendencias en Paleobiogeografía. El futuro de la biogeografía del pasado. In: Aguirre, E. (ed.). Paleontología, nuevas tendencias. C.S.I.C. Madrid: 271-296.

Robalo, J. I., Almada, V. C., Levy, A. \& Doadrio, I., 2007. Re-examination and phylogeny of the genus Chondrostoma based on mitochondrial and nuclear data and the definition of 5 new genera. Molecular Phylogenetics and Evolution, 42: 362-372. 
Robalo, J. I., Doadrio, I., Almada, V. C. \& Kottelat, M., 2005. Chondrostoma oligolepis, new replacement name for Leuciscus macrolepidotus Steindachner, 1866 (Teleostei: Cyprinidae). Ichthyological Explorations of Freshwaters, 16: 47-48.

Velasco, J. C., Peris, S. J., Pollo, C. J. \& GonzÁlez, N., 1997. Los peces de la provincia de Salamanca. Atlas de distribución. Ediciones Universidad de Salamanca. Salamanca. $172 \mathrm{pp}$.

Velasco, J. C., Rincón, P. A. \& Lobón-Cerviá, J., 1990. Age, growth and reproduction of the cyprinid Rutilus lemmingii (Steindachner, 1866) in the River Huebra, central Spain. Journal of Fish Biology, 36: 469-480.

WASSERSUG, R. J., 1976. A procedure for differential staining of cartilage and bone in whole formalinfixed. Stain Technology, 51: 131-134.
ZARDOYA, R. \& DoAdrio, I., 1998. Phylogenetic relationships of Iberian cyprinids: systematic and biogeographical implications. Proceedings of the Royal Society of London Series B-Biological Sciences, 265: 1365-1372.

ZARDOYA, R. \& DOADRIO, I., 1999. Molecular evidence on the evolutionary and biogeographical patterns of European cyprinids. Journal of Molecular Evolution, 49: 227-237.

Recibido, 9-V-2007 Aceptado, 6-IX-2007 Publicado, 27-XII-2007 